\title{
MANAJEMEN PEMBELAJARAN BERBASIS PROYEK UNTUK MELEK LITERASI
}

\author{
Santi Wahyuni \\ Universitas Islam Negeri Gunung Djati Bandung \\ Jl. A.H Nasution No. 105 Cibiru Bandung \\ Email: santiwahyunimpi@gmail.com
}

\begin{abstract}
ABSTRAK
Pembelajaran berbasis proyek merupakan salah satu model pembelajaran untuk menciptakan peserta didik yang melek literasi, dianggap relevan dengan pendidikan abad 21 (abad pengetahuan) dan era Revolusi Industri 4.0, karena sumber daya manusia yang diproses dengan model pembelajaran ini dapat mengoptimalkan pengetahuan, keterampilan, dan sikap, sehingga menghasilkan output tidak hanya manusia yang konsumtif, namun mampu menjadi ahli dan profesional dalam beragam bidang sesuai dengan potensi, minat, dan bakatnya. Tujuan penelitian untuk mengetahui manajemen pembelajaran berbasis proyek untuk melek literasi pada peserta didik. Metode penelitian yang digunakan adalah metode deskriptif dengan pendekatan kualitatif model fenomenologi, dengan teknik pengumpulan data melalui wawancara, observasi, dan studi dokumentasi. Hasil dari penelitian, terdapat efektivitas mulai dari pengamatan sampai tahap presentasi merupakan kegiatan dari melek literasi yang berhasil dicapai dengan baik. Efisiensi dalam segi waktu, peserta didik dalam waktu bersamaan dapat menggunakan beragam media dan bahan ajar serta menyampaian informasi, sedangkan secara materil tempat untuk mendapat informasi gratis, dan pembuatan proyek menggunakan barang-barang bekas. Adapun faktor pendukungnya, sumber daya manusia di sekolah yang memumpuni untuk melakukan inovasi pembelajaran yang sesuai dengan kebutuhan peserta didik saat ini. Sedangkan hambatannya adalah kurangnya manajemen waktu dalam pelaksanaan pembelajaran berbasis proyek, sehingga tidak dapat berjalan secara maksimal.
\end{abstract}

Kata Kunci: Manajemen, Pembelajaran Berbasis Proyek, Literasi

\section{ABSTRACT}

Project-based learning is one of the learning models to increase literacy of students, considered relevant to 21st century education (century of knowledge) and the era of industrial revolution 4.0, because human resources that are processed by this learning model can optimize knowledge, skills, and attitude, so as to produce output with not only consumptive humans, but able to become 
experts and professionals in various fields according to their potential, interests and talents. The purpose of the study was to determine project-based learning management to increase literacy in students. The research method used was descriptive method with a qualitative approach to phenomenological models, with techniques for collecting data was through interviews, observation, and documentation studies. Results of the study, are effectiveness ranging from observation to the percentage stage is an activity of literacy literacy that has been successfully achieved. Efficiency in terms of time, students at the same time can use a variety of media and teaching materials and deliver information, while materially place to get free information, and making projects using used goods. As for the supporting factors, human resources in schools that are qualified to make learning innovations that are suitable for the needs of today's students. While the obstacle is the lack of time management in the implementation of project-based learning, so that it cannot run optimally.

Keyword: Management, Project Based Learning, Literacy

\section{PENDAHULUAN}

Revolusi Industri 4.0 menurut Angela Merkel adalah penggabungan industri konvensional dengan teknologi digital dan internet, yang bertansformasi secara komprehensif pada aspek produksi di industri ( $\mathrm{H}$. Prasetyo \& Sutopo, 2018, hlm. 19). Menghadapi Revolusi Industri 4.0, terdapat dua jalan yang harus diperisapkan yaitu: pertama, mempersiapkan pendidikan yang sesuai antara sumber daya manusia yang dikelola dengan kebutuhan era revolusi industry, kedua, menyiapkan sumber daya manusia yang diberikan pendidikan ilmu eksakta dalam pengembangan teknologi dan ilmu sosial-humaniora untuk menjaga kualitas kemanusiaannya (B. Prasetyo \& Trisyanti, 2018, hlm. 26).

Memperkuat pernyataan sebelumnya Trilling dan Hood menyatakan, memasuki abad ke-21 sebagai abad pengetahuan sebagai landasan utama aspek kehidupan, dengan era banyak tuntutan secara spesifik yang mempengaruhi dunia pendidikan dan lapangan pekerjaan, karena perkembangan teknologi informasi, komunikasi, dan ilmu pengerahuan sosial yang berdampak merubah pemahaman manusia terhadap pendidikan, sehingga terdapat perubahan peran dan pola hubungan antara orang tua, guru, dan siswa (Rusman, 2016, hlm. 139).

Pengelolaan pembelajaran merupakan keterampilan guru untuk menciptakan iklim pembelajaran yang kondusif dan mengendalikannya jika terjadi gangguan dalam pembelajaran. Pengelolaan pembelajaran adalah cara guru menjalankan dan mengontrol aktivitas kelas, misalnya mengatur ruang kelas, kebersihan kelas, perabot kelas, startegi tempat duduk, kehadiran siswa dan hal lainnya yang ada hubungan dengan pekerjaan guru sebagai manajer kelas. Pengelolaan pembelajaran adalah cara seorang guru mengatur kelasnya dan mengembangkan tingkah laku siswa yang di inginkan serta mengurangi atau meniadakan tingkah laku yang tidak diinginkan, mengembangkan hubungan interpersonal dan iklim sosio emosional yang positif, serta mengembangkan dan mempertahankan organisasi kelas yang efektif. 
Menurut Ambarita manajemen pembelajaran adalah merupakan proses untuk mencapai tujuan pendidikan di dalam kelas secara efektif dan efisien, dengan cara guru mengoptimalkan perannya sebagai manajer kelas untuk mengelola kegiatan kerjasama pada sumber daya kelas (Rukajat, 2018, hlm. 5). Lebih lanjut menurut Ardiansyah konsep manajemen pembelajaran adalah kegiatan merencanakan, mengorganisasi, mengarahkan, mengawasi dan menilai oleh guru selama berinteraksi dengan siswa dalam pelaksanaan pembelajaran (Rukajat, 2018, hlm. 5). Sedangkan menurut Fauzi manajemen pembelajaran adalah upaya mendayagunakan potensi kelas dalam proses menuntut ilmu, sehingga tercapainya tujuan pengajaran, karena peserta didik dapat belajar dengan baik dan tertib (Fauzi, 2014, hlm. 48).

Menjalankan manajemen pembelajaran yang efektif dan efisien harus dapat memahami beberapa fungsi manajemen pembelajaran seperti perencanaan pembelajaran, pengorganisasian pembelajaran, pelaksanaan pembelajaran, penilaian pembelajaran, pengawasan pembelajaran, dan evaluasi pembelajaran.

Dalam perencanaan pembelajaran, tahapan awalnya adalah menentukan target dan tujuan untuk menciptakan perubahan peserta didik dalam kognitif atau pengetahuan, afektif atau sikap dan psikomotorik atau keterampilan (Rukajat, 2018, hlm. 16). Selanjutnya adalah menentukan strategi secara instruksional, mengatur beragam aktivitas pembelajaran, serta mengumpulkan materi pendukung (Syaifurahman \& Ujiati, 2013, hlm. 66).

Dalam pengorganisasian pembelajaran, Davis menjelaskan bahwa pengorganisasian pembelajaran adalah upaya guru dalam mengoptimalkan pengaturan dan penggunaan sumber belajar untuk mencapai tujuan pembelajara. Proses pengorganisasian yang dilakukan yaitu memilih alat dan media yang tepat, memilih jumlah murid yang tepat (jika terdapat pengelompokan belajar), memilih strategi dan pendekatan yang tepat untuk pengajaran yang kompleks (Fauzi, 2014, hlm. 253).

Dalam pelaksanaan pembelajaran, hal paling penting bagi seorang guru untuk dapat melaksanakan pembelajaran adalah bagaimana guru dapat membantu dan memfasilitasi siswa untuk mencapai tujuan pembelajaran, dengan menyesuaikan metode, latar belakang yang dibutuhkan siswa, materi yang harus disediakan, gaya serta kepribadian guru pada waktu mengajar. Terdapat beragam cara untuk mengimplementasikan pembelajaran, yaitu dengan mengajukan beberapa pertanyaan, menanmpilkan gambar, memperagakan alat peraga dan pengamatan, atau beragam cara yang membuat siswa terlibat aktif berpartisipasi selama proses pembelajaran berlangsung (Syaifurahman \& Ujiati, 2013, hlm. 66).

Aspek yang ke empat adalah penilaian pembelajaran. Penilaian disini adalah proses perolehan infromasi yang otentik terhadap penyelenggaraan pembelajaran dan keberhasilan belajar pada guru, peserta didik, dan proses pembelajaran, dengan menggunakan berbagai cara dan beragam alat untuk menghasilkan informasi. Penilaian harus dilakukan sebagai tolok ukur mengetahui hasil belajar, kemajuan pembelajaran, mencermati kesulitan belajar, memperbaiki proses dalam pembelajaran, dan sebagai penentuan kenaikan kelas peserta didik (Sobirin, 2018, hlm. 183). Pada tahap penilaian guru berusaha menghimpun informasi dengan memperhatikan reaksi siswa dengan 
memperhatikan tanggapan dan komentar atas pertanyataan yang diajukan, disesuaikan dengan mata pelajaran dan pembelajaran yang digunakan, menerapkan kuis, tes, serta menialai pekerjaan rumah (Syaifurahman \& Ujiati, 2013, hlm. 69).

Berdasarkan Permendikbud No. 22 Tahun 2016 Tetang Standar Proses Pendidikan Dasar dan Menengah, kepala sekolah satuan pendidikan dan pengawas melakukan pemantauan yang dilakukan semenjak perencanaan, tahap pelaksanaan, dan tahap penilaian hasil pembelajaran, dengan diskusi secara berkelompok, mengamati, mencatat, merekam, mewawancara, dan mendokumentasikannya. Supervisi diberikan dengan mencontohkan pembelajaran di kelas, melakukan diskusi, melakukan konsultasi, atau melaksanakan pelatihan. Hasilnya dilaporkan untuk mengembangkan keprofesionalan pendidik secara kontinu dengan pemberian penguatan kepada guru kurang optimal dan penghargaan kepada guru yang bekerja sesuai standar.

Aspek yang terakhir adalah evaluasi pembelajaran. Menurut Hamalik evaluasi pembelajaran merupakan proses evaluasi belajar mengajar dengan secara sistematis pada beragam komponen sistem pembelajaran yang dilihat dari perilaku awal peserta didik. Komponen instrumental yang di evaluasi melihat dari kemampuan pendidik atau tenaga kependidikan, komponen kurikulum (metode, media, program studi), komponen proses (prosedur pelaksanaan pembelajaran), dan komponen ketercapaian tujuan pembelajaran (Rukajat, 2018, hlm. 24). Hasil evaluasi dapat dilihat dari saling mempengaruhi antara tujuan dan strategi pembelajaran, serta teknik penilaian yang tepat dalam mencapai tujaun (Syaifurahman \& Ujiati, 2013, hlm. 71).

Salah satu model pembelajaran yang relevan dengan kebutuhan pelaksanaan pendidikan era Revolusi Industri 4.0 atau abad 21 ini adalah pembelajaran berbasis proyek. Menurut Grant, pembelajaran berbasis proyek merupakan pembelajaran yang mengkaji hubungan informasi teoritis dan praktik dalam memotivasi siswa dengan memahami apa yang dipelajari pada sebuah proyek yang nyata sehingga meningkatkan kemampuan kinerja ilmiahnya. Pengalaman pembelajaran diberikan melalui eksplorasi, penilaian, interpretasi dan mensistesis informasi, dengan memusatkan pertanyaan serta masalah, memecahkan masalah, mengambil keputusan, mencari sumber, bekerja dengan kolaborasi, dan mempresentasikan produk nyata (Rusman, 2016, hlm. 396).

Pembelajaran berbasis proyek merupakan pendekatan pembelajaran secara menyeluruh, kelas di desain sedemikian rupa untuk memungkinkan siswa melakukan penyelidikan masalah, pendalaman materi-materi pelajaran, dan melaksanakan tugasnya (Komalasari, 2017, hlm. 70). Pembelajaran berbasis proyek merupakan sebuah model pembelajaran dengan aktivitas kegiatan merancang, merencanakan, dan memproduksi produk tertentu, sebagai sarana memperoleh pengetahuan dan keterampilan, yang dalam pelaksanaannya melibatkan kurikulum inti, turun langsung ke lapangan, perpanjangan waktu lamanya belajar, pengambilan keputusan oleh siswa, keterampilan dalam bekerjasama, penilaian, dan produk proyek yang dihasilkan (Abidin dkk., 2018, hlm. 168). Pembelajaran berbasis proyek adalah salah satu strategi pembelajaran yang melibatkan siswa untuk menyelsaikan permasalahan kompleks pada masyarakat atau lingkungan, menggunakan berbagai konsep 
dan materi dalam penyelesaiannya dengan membuat suatu proyek (Sani, 2014, hlm. 172).

Penugasan proyek dapat diberikan oleh satu guru, atau beberapa guru yang mengampu pelajaran berbeda, proyek yang dilakukan oleh siswa dapat dilakukan perseorangan ataupun berkelompok (Rusman, 2017, hlm. 395). Hasil dari proyek dapat berupa alat/teknologi maupun hasil penelitian. Proyek tidak hanya dibatasi secara fisik, namun dapat berupa suatu program atau kampanye untuk mengatasi isu-isu yang sedang beredar dalam masyarakat dengan mengaplikasikan ilmu sesuai dengan pemahaman siswa (Pujayanti, 2018, hlm. 176). Peserta didik melaporkan penemuannya secara tertulis, lisan, atau dipresentasikan dalam kelas. Selain membuat siswa kreatif, siswa dapat meningkatkan kemampuan berkomunikasi saat presentasi (Daryanto \& Karim, 2017, hlm. 251).

Berikut ini merupakan gambar alur model pembelajaran berbasis proyek:

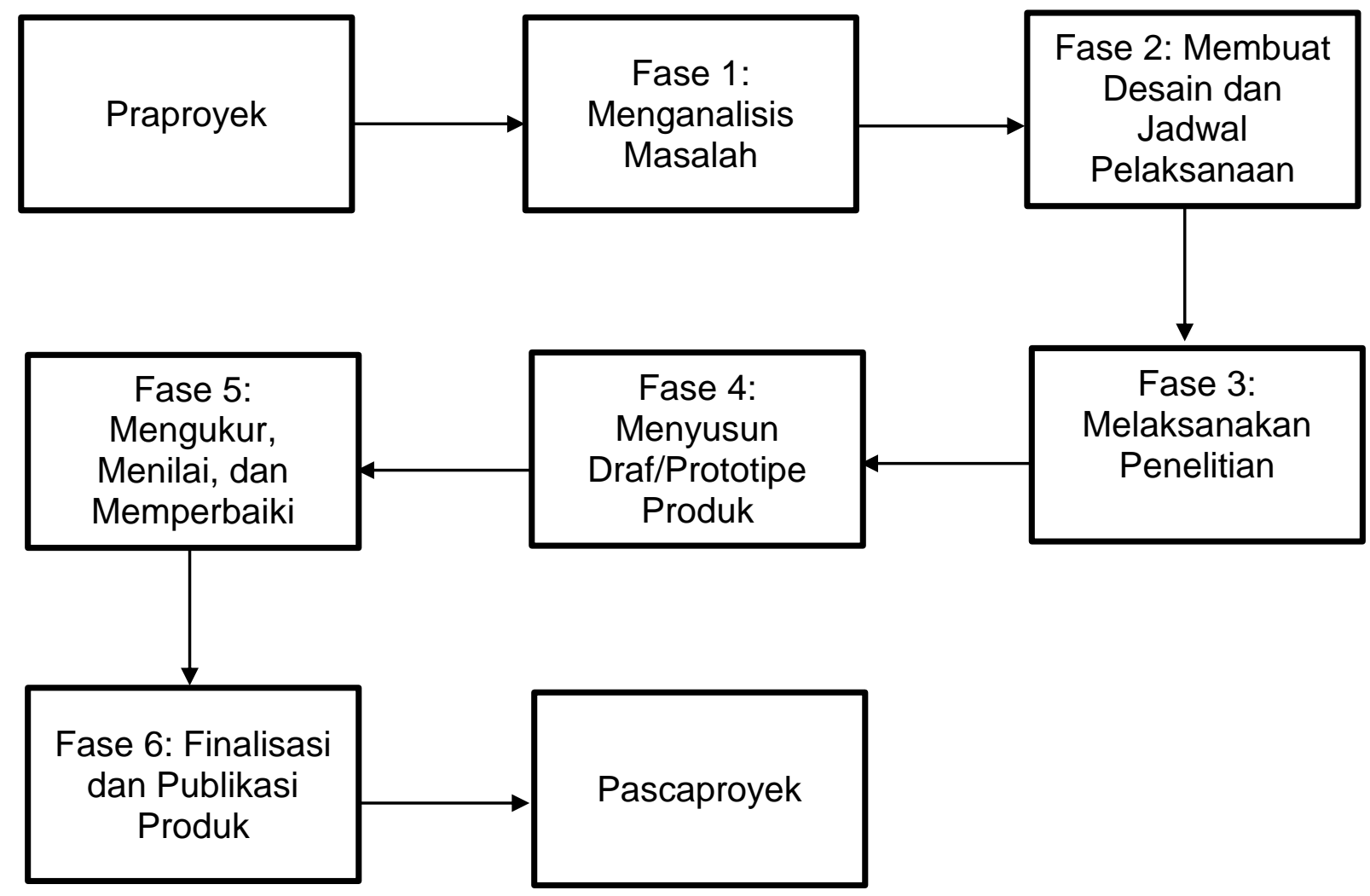

Sumber: (Abidin dkk., 2018, hlm. 172)

Gambar 1. Sintaks Model Pembelajaran Berbasis Proyek

Berdasarkan gambar tersebut menjelaskan alur dari model pembelajaran berbasis proyek yang diawali dengan tahap praproyek. Pada tahap ini perencanaan guru merancang serta mendeskripsikan proyek, menentukan tema yang akan diangkat dan permasalahan pada proyek, menyiapkan media yang akan digunakaan saat proyek, menyediakan macam-macam sumber belajar, dan menyiapkan situasi dan kondisi pembelajaran yang memumpuni. Setelah itu kemudian masuk ke fase 1 yaitu mengidentifikasi masalah. Pada fase ini siswa diberikan tugas untuk mengamati suatu obyek, dan hasil dari pengamatannya 
siswa harus meneliti permasalahannya, dibuat perumusan masalah dalam bentuk pertanyaan. Tahap berikutnya adalah fase 2 yaitu membuat desain dan jadwal pelaksanaan proyek. Dalam fase ini siswa secara bersama-sama dengan anggota kelompoknya atau bersama gruu menyusun rancangan proyek yang akan dibuat, membuat jadwal tahapan pengerjaan proyek, dan merencanakan aktivitas yang harus dilakukan. Proses yang berikutnya adalah memasuki fase 3 yaitu melaksanakan penelitian. Pada fase ini siswa mengumpulkan data yang dibutuhkan dan menganalisisnya dengan metode yang sesuai, saat melakukan penelitian. Penelitian awal dilakukan dengan tujuan untuk memberikan gambaran kepada siswa dalam membuat dan mengembangkan produk (Abidin dkk., 2018).

Tahap berikutnya adalah fase 4 yaitu menyusun draf/prototipe produk. Pada fase ini hasil dari penelitian siswa membuat contoh atau duplikasi bahkan berinovasi membuat produk yang disesuaikan dengan permasalahan yang harus diselesaikan. Fase 5 yaitu mengukur, menilai, dan memperbaiki produk. Pada fase ini siswa mengecek ulang hasil pekerjaannya, apakah produk dapat digunakan sebagaimana mestinya, atau terdapat kekurangan dan kelemahan. Selain mengecek sendiri, siswa juga dapat meminta pendapat dan masukan dari teman maupun dari gurunya. Tahap berikutnya yaitu fase 6 finalisasi dan publikasi produk. Pada fase ini setelah melakukan pengecekan ulang dan dirasa tidak ada kekurangan, siswa melakukan tahapan akhir pada produk dan dapat dipublikasikan. Tahap terakhir adalah pascaproyek. Pada tahap ini guru memberikan penilaian yang otentik dan jelas, penguatan pada hasil kerja siswa, masukan dan saran yang harus dilakukan untuk perbaikan proyek kedepannya (Abidin dkk., 2018).

Hasil dari pembelajaran berbasis proyek salah satunya adalah melek literasi. Dengan melek literasi diharapkan dapat menciptakan generasi yang unggul (Ghazali \& Hermawan, 2019). Literasi menurut Eisner adalah kegiatan menemukan dan pemaknaan dari beragam bentuk representasi sekitar yang tidak hanya dibatasi pada simbol tertulis. Selain pemberian makna, literasi merupakan kemampuan menghasilkan ide dengan beragam bentuk media untuk diinformasikan secara konvensional dalam bentuk tulisan, alat, maupun teknologi (Abidin dkk., 2018, hlm. 4).

Literasi secara tradisional adalah kemampuan seseorang dalam membaca dan menulis, seseorang yang mampu membaca dan menulis atau tidak buta huruf dianggap sebagai seorang literat. Pengertian selanjutnya berkembang tidak hanya sebatas kemampuan membaca dan menulis, namun berbicara dan menyimak. Seiring dengan perkembangan zaman literasi tidak hanya dimaknai secara sempit, akan tetapi secara luas mencakup beragam bidang. Faktor adanya perubahan adalah perluasan makna akibat dari penggunaan yang luas, terdapat perkembangan teknologi informasi, dan teknologi perubahan analogi (Abidin dkk., 2018).

Secara luas, literasi tidak hanya sekedar kegiatan membaca dan kepenulisan, namun cara seseorang pada praktik hubungan sosial yang terkait dengan bahasa, dan budaya saat berkomunikasi dalam masyarakat (Teguh, 2017, hlm. 19). Salah satu usaha agar dapat menjadi orang yang literat dalam masyarakat, terdapat gerakan literasi di sekolah, yakni melatih kemampuan peserta didik dalam melihat, menyimak, membaca, menulis, dan berbicara, 
dengan mengakses, memahami, dan menggunakan sesuatu secara cerdas (Silvia \& Djuanda, 2017, hlm. 161).

Gambaran di Sekolah Menengah Pertama Islam Cendekia Muda Bandung, merupakan salah satu sekolah yang menjadi pionir penerapan pembelajaran berbasis proyek dengan pendekatan STEM ( Science, Technology, Engineering, and Mechanic) di Kota Bandung, sekolah menjadi perwakilan Kota Bandung dalam acara workshop STEM dan Revolusi Industri 4.0 yang diadakan oleh Kemdikbud, serta dinobatkan sebagai sekolah percontohan untuk pembelajaran berbasis proyek bersama delapan sekolah lainnya pada tingkat nasional. Pembelajaran berbasis proyek yang diterapkan oleh sekolah melalui beberapa program, yaitu; fieldtrip, project day, workshop, seminar, diorama dan display class. Pada program-program tersebut peserta didik menghasilkan literasi dalam bentuk karya tulis ilmiah maupun produk praktis dengan mengintegrasikan teori semua mata pelajaran yang dipelajari sebelumnya di kelas, sesuai tema yang ditentukan oleh sekolah.

\section{METODE PENELITIAN}

Terdapat enam langkah penelitian yang dilakukan, yaitu: 1) penentuan pendekatan dan metode penelitian; 2) penentuan jenis dan sumber data; 3) penentuan teknik pengumpulan data; 4) penentuan teknik analisis data; 5) penentuan uji absah data; 6) penentuan tempat dan waktu penelitian. Pendekatan yang dilakukan dalam penelitian adalah pendekatan kualitatif dengan model fenomenologi. Pendekatan kualitatif adalah mengarahkan peneliti dalam mencapai tujuan penelitian dengan mendapatkan penjelasan secara mendalam pada penerapan sebuah teori serta berpikir secara induktif (Indrawan \& Yaniawati, 2016, hlm. 29). Penelitian kualitatif menurut Williams ialah kegiatan mengumpulkan data pada latar yang alamiah, dengan metode alamiah, dan dilakukan oleh peneliti yang tertarik secara alamiah (Moleong, 2018, hlm. 5). Fenomenologi merupakan strategi yang mewajibkan peneliti untuk menelaah beberapa subjek dengan berpartisiapasi secara langsung dalam kurun waktu yang cukup lama untuk mengembangkan pola dan relasi (Creswell, 2017, hlm. 22-23). Sedangkan metode penelitian menggunakan metode deskpriptif. Sukmadinata menjelaskan penelitian deskriptif merupakan bentuk penelitian untuk mendeskripsikan fenomena-fenomena yang ada dilapangan secara alamiah maupun buatan. Fenomena dapat berupa karakteristik, aktivitas, hubungan, perubahan, kesamaan dan perbedaan antara satu fenomena dengan fenomena lainnya (Suryana, 2015, hlm. 152-153).

\section{HASIL DAN PEMBAHASAN}

Pembelajaran berbasis proyek semester genap tahun pelajaran 2018/2019 dilaksanakan pada bulan Februari dengan konsep TPoC (Team Project of Colaboration) atau Kolaborasi Proyek Tim, dan bulan Maret dengan konsep MPoC (My Project of Colaboration) atau Kolaborasi Proyek Individu. Penulis meneliti manajemen pembelajaran berbasis proyek dengan konsep TPoC pada kelas VII, dan manajemen pembelajaran berbasis proyek dengan konsep MPoC pada rumpun Pendidikan Agama Islam dan Bahasa Arab di kelas VII dan VIII. 
Perencanaan diawali dengan rapat membahas tujuan, landasan, latar belakang, tema kolaborasi, penentuan tempat fieldtrip, dan tahapan pembelajaran berbasis proyek. Pendidik diberikan kewenangan untuk mengangkat salah satu tema dalam mata pelajaran yang diampu untuk dijadikan bahan dalam pembelajaran berbasis proyek. Setelah menentukan tema, pendidik diminta untuk mempresentasikan dihadapan peserta rapat. Kepala sekolah dan wakil kepala sekolah bidang kurikulum membuat kerangka awal untuk program TPoC dari hasil pemaparan para pendidik. Tema besar TPoC untuk kelas VII adalah "Pengolahan Sampah Terpadu Sebagai Solusi Pencemaran Lingkungan". Latar belakang pengangkatan tema tersebut disebabkan karena pencemaran lingkungan merupakan masalah serius. Sebagai contoh nyata TPA Sari Mukti yang menampung sampah buangan dari Kota Bandung sudah mencapai muatan maksimal. Oleh sebab itu, TPoC kali ini mengangkat tema pengolahan sampah organik.

Sedangkan untuk MPoC rapat pertama dihadiri semua pendidik mata pelajaran yang sudah dikelompokan per rumpun, pengelompokan berdasarkan keterkaitan tema mata pelajaran satu sama lain. Terdapat 5 lima rumpun yaitu Matematika dengan IImu Pengetahuan Alam, IImu Pengetahuan Sosial dengan Pendidikan Kewarganegaraan, Bahasa Indonesia dengan Bahasa Inggri dan Bahasa Sunda, Pendidikan Agama Islam dengan Bahasa Arab, Pendidikan Jasmani Olahraga dan Kesehatan dengan Seni dan Kriya. Pendidik berkumpul per rumpun untuk membahas tema yang akan diangkat, merumuskan latar belakang, mempresentasikan hasil diskusi awal, menentukan tempat fieldtrip, penentuan tanggal kunjungan, membuat proposal anggaran yang akan diajukan kepada kepala sekolah dan administrasi keuangan sekolah. Rumpun Pendidikan Agama Islam dengan Bahasa Arab akan melakukan kunjungan ke dua tempat, yaitu Mesjid Al-Lathif dengan narasumber Kang Kiki Mantan Ketua Brigez untuk kelas VII, dan Badan Narkotika Nasional untuk kelas VIII. Pembahasan pun dilanjutkan dengan teknis pelaksanaan, pembuatan jadwal dan membuat rubrik penilaian. Tema yang diambil oleh rumpun Pendidikan Agama Islam dengan Bahasa Arab untuk kelas VII adalah "Khalifah fil ardh" sebagaimana mengambil landasan Q.S AI-Baqarah ayat 30. Sedangkan untuk kelas VIII bertema "Human of Excellence". Tiga hubungan penting yang senantiasa dilalui manusia mencakup Hablum Minallah, Hablum Minannas, dan Hablum Minal Alam.

Pengorganisasian dalam pembelajaran berbasis proyek membahas peran dari pendidik dan tenaga kependidikan yang terlibat dalam pembelajaran berbasis proyek, pembahasan jadwal mulai dari awal pelaksanaan sampai pada tahap penilaian, serta menjelaskan proses tahapan TPoC dan MPoC dari awal sampai akhir.

Peran kepala sekolah dalam pembelajaran berbasis proyek adalah pemimpin dan pengawas dalam kegiatan, kepala sekolah yang berhak menentukan dan mengarahkan proses pembelajaran berbasis proyek secara keseluruhan. Wakil kepala sekolah bidang kurikulum bertugas mencatat semua agenda yang dirumuskan oleh kepala sekolah, sedangkan tugas koordinator lapangan diberikan kepada wali kelas, untuk pendidik bidang studi memiliki tugas membimbing peserta didik dalam pembuatan alat proyek, karya tulis ilmiah, dan power point pada TPoC. Sedangkan pada MPoC koordinator lapangan dan pembimbing proyek dilakukan oleh guru rumpun. 
Peserta didik fieldtrip yang pertama berkunjung ke ITB Jatinangor untuk mendapatkan materi pengelolaan sampah dengan alat pengelolaan sampah organik dan nonorganik. Peserta didik mengisi lembar kerja siswa yang disediakan sekolah untuk bahan pembuatan alat dan karya tulis ilmiah, serta diberikan kesempatan untuk bertanya. Lokasi kedua fieldtrip ke Kampung Sehat Cibunut, pada lokasi kedua diadakan seminar mengenai lingkungan sehat dan cara pengelolaan limbah sampah secara terpadu, dengan narasumber yang merupakan salah satu aktivis lingkungan Bandung.

Tahap pembuatan desain produk, peserta didik terinspirasi dengan alatalat yang ada di ITB Jatinangor dan berusaha untuk membuat prototypenya, adapun beberapa peserta didik memilih untuk mencari ide bentuk produk dari internet dan dikembangkan sendiri. Desain yang dibuat beragam, dalam bentuk alat pencacah sampah, alat penumbuk sampah, dan alat pengering sampah. Peserta didik diberikan waktu selama empat hari untuk pembuatan produk dan penulisan karya tulis ilmiah. Satu kelompok terdiri dari enam sampai tujuh orang, sehingga setiap peserta didik memiliki tugas masing-masing yang telah ditugaskan oleh ketua kelompok, ada yang bertugas untuk membuat produk, karya tulis ilmiah, dan desain STEM expo.

Tahap terakhir, peserta didik membuat STEM expo yang nantinya dijadikan tempat pameran hasil produk praktis bagi para pengungjung, sedangkan untuk presentasi peserta didik diminta untuk datang ke ruangan seminar untuk diuji oleh tiga orang penguji dan dihadiri orangtua peserta didik, pendidik dari SMP Alfa Centauri dan SMP Harapan Bunda yang studi banding, dan kepala Kurikulum Disdik Bandung untuk melihat proses dari penerapan pembelajaran berbasis proyek di sekolah percontohan. Peserta didik akan diuji oleh penguji, dengan mempresentasikan hasil produk, dan karya tulis ilmiah menggunakan media power point. Penguji mengomentari atau memberikan beberapa pertanyaan yang terkait dengan hasil kerja peserta didik.

Pada pelaksanaan MPoC Peserta didik melalukan perjalanan fieldtrip ke Mesjid Al-Lathif dengan narasumber Kang Kiki, mantan Ketua Brigez untuk tema kelas VII, Kang Kiki menceritakan perjlanan hijrahnya dan mengaitkan pembahasan ikhlas, sabar dan pemaaf dalam melakukan proses hijrah menuju manusia yang lebih baik. Peserta didik kelas VIII mendapat data di Badan Narkotika Nasional yang membahas minuman keras dan keterkaitannya dengan perkelahian dalam kehidupan.

Hasil karya peserta didik dalam bentuk karya tulis ilmiah harus memuat hal-hal sebagai berikut, yaitu: judul karya tulis ilmiah, latar belakang masalah, rumusan masalah, tujuan penelitian, kajian pustaka, hasil penelitian dan pembahasan, kesimpulan, dan daftar pustaka. Selain karya tulis ilmiah peserta didik harus membuat project board untuk media presentasi.

Pada tahap penilaian, peserta didik memasuki ruang seminar yang akan diuji oleh tiga penguji yang membahas produk praktis, karya tulis ilmiah, dan performa presentasi. Audien dari seminar adalah orangtua peserta didik yang sedang mempresentasikan hasil tugansya. Selain penilaian seminar presentasi, stand pameran proyek yang dibuat oleh peserta didik untuk dikujungi pengunjung mendapat penilaian secara lansgung dari orangtua peserta didik. Penilaian hasil kerja peserta didik selama pembelajaran berbasis proyek untuk konsep TPoC 
terdapat empat kategori penilaian yaitu produk praktis, karya tulis ilmiah, power point, dan booth kelompok.

Format penilaian MPoC dengan TPoC tidak jauh berbeda, hanya untuk MPoC penilaian kerja individu yang didasarkan dari hasil karya tulis ilmiah dan project board, serta menilai performa peserta didik saat mempresentasikan. Terdapat orangtua peserta didik yang berada dalam ruang sidang untuk melihat anaknya presentasi dan memberikan pertanyaan atau komentar secara langung kepada hasil kerja anaknya, serta masukan bagi sekolah.

Pengawasan dilakukan langsung oleh kepala sekolah dan dibantu oleh wakil kepala sekolah bidang kurikulum. Pada setiap tahapnya kepala sekolah memantau langsung ke lapangan, maupun tidak langsung dengan mendapat laporan dari wakil kepala sekolah bidang kurikulum atau pendidik. Kepala sekolah mengecek ke dalam kelas apakah peserta didik mengerjakan sesuai dengan yang ditugaskan atau tidak, mengecek kehadiran guru pembimbing untuk melakukan bimbingan kepada peserta didik, bertanya langsung kepada pendidik dan peserta didik mengenai proses setiap tahapan dan menanyakan kendala atau kesulitan yang dialami, jika terjadi hambatan kepala sekolah mencoba mencari alternatif solusi.

Selain pendidik yang di cek oleh kepala sekolah, pendidik memiliki tugas untuk melakukan monitoring terhadap pekerjaan peserta didik, selain pelaksanaan yang dapat diawasi langsung di sekolah, pendidik juga bekerjasama dengan orangtua untuk selalu melaporkan setiap proses dari pengerjaan proyek dengan tujuan peserta didik dapat menyelesaikan proyeknya sesuai dengan target jadwal yang telah ditentukan.

Evaluasi TPoC dilaksanakan setelah STEM Expo selesai, dihadiri oleh kepala sekolah, wakil kepala sekolah bidang kurikulum dan seluruh pendidik yang terlibat dalam pembelajaran berbasis proyek. Evaluasi dimulai dari tahapan pertama dalam pembelajaran berbasis proyek, yaitu apersepsi dengan fieldtrip. Peserta didik merasa kesulitan selain harus mendengarkan atau memperhatikan narasumber, mereka harus mengisi lembar kerja siswa (worksheet) sebagai bahan pembuatan proyek dan karya tulis. Solusinya, akan diberikan waktu pengisian worksheet setelah narasumber selesai menjelaskan.

Proses pembuatan alat proyek dan karya tulis ilmiah, peserta didik dinilai sudah paham dan mengerjakan, namun menurut keterangan beberapa pendidik, terdapat beberapa peserta didik yang tidak dapat bekerja dalam tim, dan performanya lebih kurang daripada mengerjakan sendiri. Salah satu tujuan adanya pembelajaran berbasis proyek dengan konsep tim adalah menjadikan peserta didik tidak individualistik dan dapat belajar bekerjasama. Sedangkan evaluasi orangtua berupa pengisian kuisoner, rata-rata mengeluhkan waktu TPoC yang sangat singkat, sehingga anak mereka tidak dapat melakukan yang maksimal, orangtua meminta untuk diberikan waktu yang cukup lama dalam pelaksanaan TPoC terutama saat pembuatan produk dan karya tulis ilmiah. Selebihnya orangtua memberikan respon yang positif.

Evaluasi pada konsep MPoC dilakukan langsung oleh orangtua peserta didik dengan memberikan masukan kepada pihak penguji, menjelaskan hambatan yang dialami anaknya saat pengerjaan MPoC. Penguji mencatat semua yang disampaikan oleh orangtua peserta didik. Catatan tersebut akan menjadi bahan pertimbangan perbaikan yang akan dilakukan oleh kepala 
sekolah pada pembelajaran berbasis proyek semester selanjutnya. Selain itu sekolah membuat kuisoner yang harus diisi dengan beberapa pertanyaan mengenai tanggapan orangtua terhadap pelaksanaan MPoC. Evaluasi secara keseluruhan, pelaksanaan MPoC lebih baik daripada TPoC karena adanya fokus bahasan dari rumpun yang peserta didik minati, dan lebih bisa dinilai hasil pekerjaannya karena dilaksanakan secara individu.

Hasil manajemen pembelajaran dengan konsep TPoC untuk melek literasi peserta didik, terdapat efektivitas dari segi kegiatan daripada hanya membaca buku mata pelajaran atau belajar di dalam kelas, karena peserta didik mendapatkan informasi dari beragam media dan kegiatan, serta dapat menginformasikan kembali atau memberikan solusi dari hasil temuan permasalahan saat dikaji dengan lebih optimal. Pada proses pembuatan produk proyek, peserta didik melihat keadaan lapangan tentang kebersihan lingkungan, mencari penyebab problematiknya, dan mencari solusi untuk menyelesaikan masalah dengan membuat produk proyek berdasarkan hasil apersepsi dari sumber yang relevan, sedangkan pada pembuatan karya tulis ilmiah terdapat kegiatan membaca dan menulis sesuai dengan kaidah kepenulisan penelitian yang sederhana, sehingga membuat peserta didik mengenal lebih dini mengenai karya tulis ilmiah. Power point sebagai media presentasi memberikan kemudahan bagi peserta didik untuk menjelaskan hasil penelitiannya kepada para audiens atau penerima informasi dengan memanfaatkan teknologi, sehingga lebih mudah dipahami.

Efektivitas dari konsep MPoC untuk melek literasi, peserta didik mendapat materi langsung dari narasumber untuk bahan karya tulis ilmiah, dan melakukan penelitian sederhana kepada teman di sekolah, hasil karya tulis ilmiah sederhana sangat baik karena mendapat data yang relevan dan peserta didik mampu mengsingkronkan dengan tema yang diangkat. Project board sebagai media presentasi memudahkan peserta didik untuk menjelaskan hasil dari penelitiannya, karena terdapat poin-poin penting yang tertera, dan memudahkan para audiens yakni penguji dan orangtua saat peserta didik menjelaskan hasil pekerjaannya karena terdapat media presentasi yang dapat diperhatikan bersama, sehingga informasi yang ingin disampaikan peserta didik dapat diterima baik oleh audiens.

Efisiensi dari kedua konsep TPoC dan MPoC, dari segi waktu yang singkat kurang dari satu minggu, peserta didik dapat menyerap informasi dari beragam sumber pembelajaran, mengelola informasi, menganalisa permasalahan, memecahkan masalah, dan membuat solusi, serta menginformasikan kembali hasil dari ide dan gagasan berupa produk dan karya tulis ilmiah kepada audiens. Sedangkan dari segi biaya lebih murah karena tempat fieldtrip memanfaatkan fasilitas dari pemerintah yang gratis serta masih berada dilingkungan Kota Bandung sehingga mudah dijangkau, pembuatan produk proyek memanfaatkan barang bekas dan sampah, sehingga menekan biaya yang harus dikeluarkan oleh peserta didik.

Faktor utama pendukunng dari keberlangsungan pembelajaran berbasis proyek adalah sumber daya manusia yang dimiliki oleh sekolah, pihak yayasan selaku pengelola utama sekolah yang sangat terbuka dengan perubahan zaman sehingga melakukan beragam penelitian dan inovasi dalam pelaksanaan pembelajaran, kepala sekolah dan tenaga kependidikan yang dapat bekerja 
secara maksimal meskipun memiliki kesibukan administrasi yang harus dipenuhi untuk pemenuhan standar proses secara nasional, pendidik yang mau belajar berbagai hal baru dan mau belajar bersama untuk kepentingan peserta didik, peserta didik yang aktif dan antusias dengan beragam program yang diadakan oleh sekolah, serta dukungan dari orangtua kepada anaknya dan sekolah secara moril maupun materil dengan tidak keberatan untuk membiayai semua proses pembelajaran berbasis proyek, dengan tujuan anaknya mendapatkan pengalaman belajar yang relevan sesuai dengan kebutuhannya.

Faktor penghambat terjadi secara teknis karena tidak adanya manajemen waktu yang baik dari peserta didik maupun pendidik dalam pelaksanaan semua konsep pembelajaran berbasis proyek pada TPoC maupun MPoC, keluhan kurangnya waktu yang diberikan sekolah tidak dapat menajdi alasan, karena pembelajaran berbasis proyek menjadi salah satu model pembelajaran yang diterapkan di sekolah dengan kurun waktu yang sudah ditetapkan, maka jika melaksanakannya lagi pada tahun ajaran selanjutnya, tidak akan ada penambahan waktu. Salah satu solusinya adalah dengan melatih pendidik maupun peserta didik untuk dapat manajemen waktu dengan baik, melaksanakan setiap tahapan sesuai dengan jadwal yang ditentukan.

\section{SIMPULAN}

Manajemen pembelajaran berbasis proyek dimulai dari tahap perencanaan dengan menganalisis kebutuhan peserta didik dengan mengangkat permasalahan yang terjadi di lingkungan sekitar dan membuat konsep dalam bentuk kelompok (TPoC) serta individu (MPoc), penentuan tujuan yang akan dicapai, penentuan tema besar, dan tema pada setiap mata pelajaran yang akan dimasukan ke dalam pembelajaran berbasis proyek. Pada tahap pengorganisasian terdapat kegiatan pembuatan tahapan program, jadwal kegiatan, dan jalur koordinasi. Pelaksanaan pembelajaran berbasis proyek, dimulai dengan pembukaan yang berisi penjelasan konsep, dan pemaparan rangkaian kegiatan, pelaksanaan fieldtrip ke ITB Jatinangor dan Kampung sehat Cibunut untuk TPoC, dan Mesjid Al-Latihif serta Badan Narkotika Nasional untuk MPoC, setelah fieldtrip peserta didik membuat produk dan karya tulis ilmiah sederhana, serta power point dan project board untuk membantu mempresentasikan saat seminar penilaian, tahap terakhir dari pelaksanaan adalah pembuatan STEM Expo, yakni stand proyek untuk dikunjungi oleh pengungjung (orangtua peserta didik). Tahap penilaian, diuji oleh tiga penguji guru bidang studi dengan ketentuan atau kriteria penilaian dari produk praktis, karya tulis ilmiah, dan performa saat presentasi. Semua tahapan diawasi langsung oleh kepala sekolah, kepala sekolah siap sedia untuk konsultasi memberikan jalan alternatif jika terjadi kendala atau kesulitan saat pelaksanaan. Evaluasi dilakukan setelah semua kegiatan selesai, kepala sekolah memimpin langsung evaluasi, dengan mendengarkan laporan dari setiap guru dan hasil dari kuisoner orangtua peserta didik.

Faktor pendukung dalam pelaksaan pembelajaran berbasis proyek adalah pendidik yang mau belajar, bahwa konsep TPoC dan MPoC adalah program baru yang dilaksanakan oleh sekolah, selain itu peran kepala sekolah dan pihak yayasan yang open minded terhadap perkembangan pendidikan dan menanggapi pendidikan 4.0 dengan melakukan perubahan yang sesuai dengan 
kebutuhan dan tuntutan zaman, namun menyesuiakan dengan kebutuhan peserta didik. Sedangkan hambatannya adalah kurangnya manajemen waktu dalam pelaksanaan pembelajaran berbasis proyek, sehingga tidak dapat berjalan secara maksimal.

\section{REFERENSI}

Abidin, Y., Mulyati, T., \& Yunansah, H. (2018). Pembelajaran Literasi (Stretgi Meningkatkan Kemampuan Literasi Matematika, Sains, Membaca, dan Menulis). Bumi Aksara.

Creswell, J. W. (2017). Research Design (Pendekatan Metode Kualitatif, Kuantutatif, dan Campuran). Pustaka Pelajar.

Daryanto, \& Karim, S. (2017). Pembelajaran Abad 21. Gava Media.

Fauzi, A. (2014). Manajemen Pembelajaran (Edisi Revisi: Kurikulum Nasional 2013). Deepublish.

Ghazali, D. A., \& Hermawan, A. H. (2019). Membangun Generasi Unggul Dengan Budaya Literasi Melalui Kepemimpinan Pendidikan. Jurnal Isema: Islamic Educational Management, 2(1). https://doi.org/10.15575/isema.v2i1.4992

Indrawan, R., \& Yaniawati, P. (2016). Metodologi Penelitian Kuantitatif, Kualitatif, dan Campuran untuk Manajemen, Pembangunan, dan Pendidikan. PT Refika Aditama.

Komalasari, K. (2017). Pembelajaran Konstektual (Konsep dan Aplikasi). PT Refika Aditama.

Moleong, L. J. (2018). Metodologi Penelitian Kualitatif. PT Remaja Rosdakarya.

Prasetyo, B., \& Trisyanti, U. (2018). Revolusi Industri 4.0 dan Tantangan Perubahan Sosial. IPTEK: Journal of Proceedings Series, 5, 22-27. https://doi.org/10.12962/j23546026.y2018i5.4417

Prasetyo, H., \& Sutopo, W. (2018). Industri 4.0: Telaah Klasifikasi Aspek Dan Arah Perkembangan Riset. J@ti Undip : Jurnal Teknik Industri, 13(1), 17. https://doi.org/10.14710/jati.13.1.17-26

Pujayanti, T. (2018). Mengajar Sains yang Menyenangkan di dalam Kelas. CV Andi Offset.

Rukajat, A. (2018). Manajemen Pembelajaran. Deepublish.

Rusman. (2016). Model-Model Pembelajaran. PT Grafindo.

Rusman. (2017). Belajar dan Pembelajaran (Berorientasi Standar PProses Pendidikan). Kencana.

Sani, R. A. (2014). Pembelajaran Saintifik untuk Implementasi Kurikulum 2013. PT Bumi Aksara.

Silvia, O. W., \& Djuanda, D. (2017). Model Literature Based Dalam Program Gerakan Literasi Sekolah. Mimbar Sekolah Dasar, 4(2), 160-171. https://doi.org/10.23819/mimbar-sd.v4i2.7799

Sobirin. (2018). Kepala Sekolah, Guru dan Pembelajaran. Nuansa Cendekia.

Suryana, Y. (2015). Metode Penelitian Manajemen Pendidikan. CV Pustaka Setia.

Syaifurahman, \& Ujiati, T. (2013). Manajemen dalam Pembelajaran. Indeks.

Teguh, M. (2017). Gerakan Literasi Sekolah Dasar. Seminar Aktualisasi Kurikulum 2013 di Sekolah Dasar Melalui Gerakan Literasi Sekolah untuk Menyiapkan Generasi Unggul Berbudi Pekerti, Universitas Muria 
Santi Wahyuni

Kudus Jawa Tengah.

http://pgsd.umk.ac.id/files/prosiding/2017/3\%20Mulyo\%20Teguh.pdf 